\title{
Effectiveness of Voluntary Disclosure the Public Trust (Comparative Study of Successful Voluntary Disclosure on Corporate Cigarette)
}

\author{
Dra. Ec. Tri Lestari, M.Si. \\ Departement Accounting Fakulty Economic University Bhayangkara Surabaya East Jawa in Indonesia.
}

\begin{abstract}
The problem in this study is, Why conduct and management decision making voluntary disclosure, voluntary disclosure How is decision-making, affecting the securities company?, And how to determine the level of voluntary disclosure (the level of voluntary disclosure) in the annual report?., The purpose of this study was to determine how the decision-making voluntary disclosure decision-making of companies that have gone public, knowing what influences the decision making of managers in the voluntary disclosure enter price and knowing determining the level of voluntary disclosure (the level of voluntary disclosure) in the annual report.

Methods of data analysis in this study was developed by Strauss and Corbin, a 33 element refers to voluntary disclosure. The result of the research show that, There is a tendency information of the estimation or planning of the company's target is not disclosed to public, for example: information of the sale estimation for the next coming year, information of the amount of cash flow the next coming year and so on.
\end{abstract}

Key Words: Effectiveness, Voluntary, Disclosure, Decision, The public trust.

\section{Introduction}

One objective of financial statements is the provision of information about a company's financial condition for the decision making managers. This requires disclosure (disclosure) adequate financial data, as well as the objective for making the right decision. The annual report contains the company's financial condition and other information, used to be communicated to shareholders, creditors, stockholders, prospective stockholders and other interested parties. Disclosure (disclosure) the financial statements can be grouped into two, namely:. 1, the disclosures required (mandatory disclosure) which is the disclosure of the information required by the regulations set by the authority. Regulations governing mandatory disclosure in the annual report issued by the government of Indonesia through the Chairman of Bapepam Decree No.. Kep-17/PM/1995, as amended by decision of the chairman of the Securities and Exchange Commission No.. Kep-38/PM/1996. In previous regulatory classification does not include companies of medium and small companies. In the enactment of new regulations therein load of all companies that have made a public offering and companies go public.. 2, the voluntary disclosure (voluntary disclosure), is in excess of the disclosure required by the regulations. In this context, management companies choose to provide accounting information and other information deemed relevant and useful for decision support and decision by users of annual reports (Meek et al, 1995). (1) Refers to the existing regulations in Indonesia, this voluntary reporting (Voluntary Disclosure) remain relevant to the interests of the decision-making by the users of the report.

Hendriksen and Breda $(1992,774)(2)$ states in relation to the concept of net income (enterprise net income), as follows:

".... In the enterprise theory, the corporation is a social institutional operated for the benefit of many interested groups. In the broadest form these groups include, in addition to the stockholders and creditors, the employees, customers, the government as taxing authority and as a regulatory agency, and the general public ".

Vice versa, the agent wants to maintain his desire and wish she did moral hazard for the purposes of satisfying the interests can be achieved (Jensen and Meckling 1976). (3).

\section{Conceptual Framework.}

Relationship of the company and the various factors that may affect the decision of the management in determining the extent of voluntary reporting (Voluntary Disclosure), in this study. Conceptually can author pointed out in the following chart: 
Figure 1 Conceptual framework Wide Voluntary Disclocure company went public

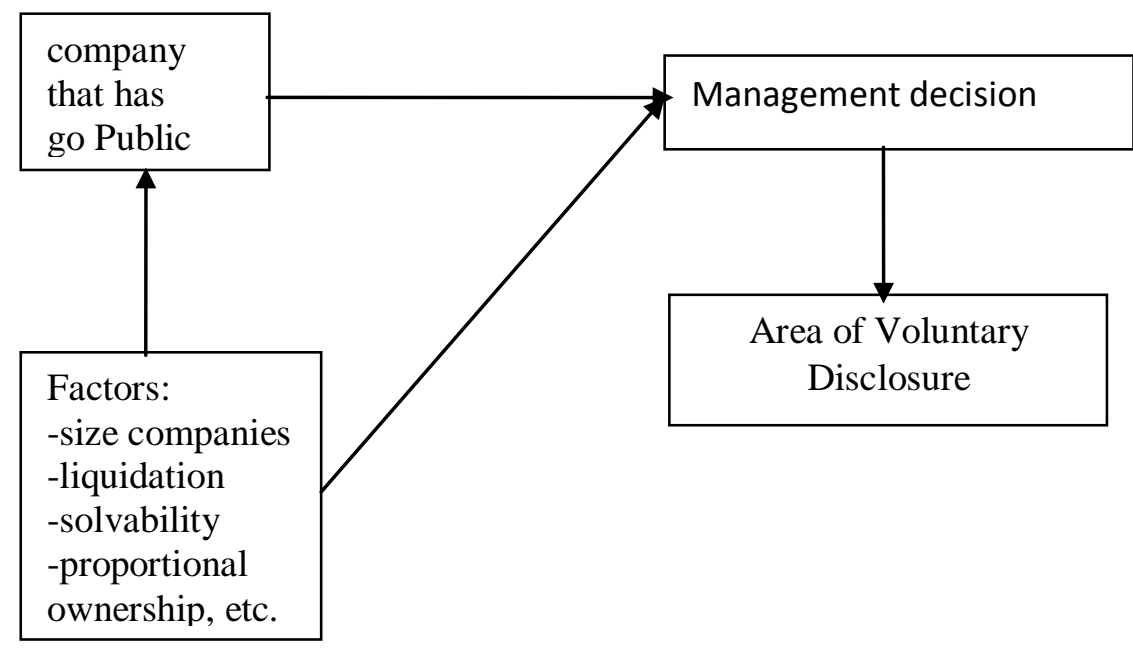

II. Methods.

The method used in this study is qualitative research (Moleong, 2000, 5) (4) and the attractions of this study are the elements of voluntary disclosure, in which tobacco companies have gone public. To obtain a complete picture of the object of this study, researchers will take steps Conducting surveys and observations prior to the publicly listed company on the Jakarta Stock Exchange, based on the annual report presented an overview will be acquired large companies that have gone public in Java East. Furthermore determined three tobacco companies that are considered representative writers representing tobacco companies that have gone public in East Java, Referring to the opinions expressed by Meek et.al (1995) (5) authors determined 33 elements of voluntary disclosure, to studied through information submitted by The three companies studied in the annual report of each company, Next to perform triangulation (Nasution, 1988, h9), (6) in order to obtain data on voluntary disclosure elements are delivered through the company's annual report, the authors checked the validity each company studied. Especially in the sources of information (key person) who has the authority, to explain the elements of voluntary disclosure through the annual report submitted each company, data obtained through the Surabaya Stock Exchange, and then compared with the information obtained in the three companies studied. Then analyzed, various matters relating to these reasons the decision to provide or not the public, 33 elements of voluntary disclosure, whether the company PT.HM. Sampoerna, Tbk, PT. Gudang Garam Tbk, Indonesia PT.BAT, Tbk. while methods of data analysis in this study the authors performed data analysis as developed by Strauss and Corbin (1990, 61-142) (7)..

\section{Results And Discussion.}

In this study, the authors will present data, especially concerning elements Voluntary Disclosure, of the three companies Cigarettes are determined in this study. As raised by Meek et. al. (1995) (5) factors affecting the Wide Voluntary Disclosure Go public companies in the U.S., UK, and mainland Europe, there are three types of strategic information that includes information, non-financial information, and financial information.

The elements of all three types of information, according to Suripto (1998), (8) as used in this study consisted of 33 elements of information to be presented in this section and shall be analyzed in the next section on Voluntary Disclosure three companies studied .

The research was carried out within a period of time, this is done considering the number of study subjects and the conditions beyond the ability of researchers that the head of the company which are difficult to contact because of his work, as an object of research. The study began with a pre-survey to the company conducted in the months of June 2003, which was followed in September 2003, the Surabaya Stock Exchange until November 2003. The results obtained from the Surabaya Stock Exchange in order to obtain objectivity, through a process of triangulation then conducted Cross Check to the companies researched, namely PT. BAT Indonesia, PT. Gudang Garam and PT. HM. Sampoerna, to get more information about the Voluntary Disclosure as disclosed in the public through the Stock Exchange.. Meek et al. (1995) (5) suggested, studies in various multinational companies in U.S., UK and mainland Europe, is generally spacious Voluntary Disclosure can be divided into three types of information, namely: 1) Strategic Information, 2) non-financial information, and 3) The financial information. A further implication of these differences in orientation, are all elements that can be considered an important study by one of the companies to be disclosed to the public. On the other hand, is considered to be an important element disclosed to the public by any other company. However, there are elements that all companies studied, considered essential to be disclosed to the public. So there are elements of 
certain voluntary disclosure, that not all companies disclose, those particular elements that all companies disclose and there are certain elements that are considered important by all companies surveyed to be disclosed to the public..

Judging from the nature disclosure, disclosure of information to the public, it is necessary for investors to assess the relative risks that exist in a company before they decide portfolio shares of various tobacco company (diversifified portfolio) and a combination of investments that meet risk preference. How much information should be disclose, not only depends on the consideration of the manager (internal), but can also be influenced by the objective conditions of the corporate environment (external) in which they operate. In accordance with the opinion of Theodore M. Tuananakotta $(2000,221),(9)$ stated that: "there are three concepts proposed disclosure, each is disclosure an adequate (adequate), fair (decent), and full (full). It is as well delivered by Hendriksen $(1990,504-505)$ (10) as follows: "The most commonly used of these is adequate disclosure expression. But this implies a minimum amount of disclosure negative congruous with the objective of making the statements not misleading. Fair and full concepts are more positive. Fair disclosure implies an ethical objective of providing equal treatment for all potential readers. Presentation implies the full disclosure of all relevant information. ". In accordance with the study conducted on the three companies studied, differences in the level of expression of each company each company will be grouped according to the three properties, which the company gives expression categorized in at least adequate disclosure, companies that provide extensive disclosures between the two companies Another categorized as fair disclosure, while providing the most disclosure categorized as full disclosure..

Of the 33 elements studied in each company, can be expressed broad disclosure as shown in the following table.

Table 1 Resume Voluntary Disclosure Each Company

\begin{tabular}{|c|c|c|c|c|}
\hline No. & INFORMATION ITEM DESCRIPTION & $\begin{array}{c}\text { PT. BAT } \\
\text { INDONESIA } \\
\end{array}$ & $\begin{array}{c}\text { PT. } \\
\text { GUDAN } \\
\text { G } \\
\text { GARAM }\end{array}$ & $\begin{array}{l}\text { PT. H.M. } \\
\underline{\text { SAMPOE }} \\
\underline{\text { RNA }}\end{array}$ \\
\hline A. & Strategic Information & & & \\
\hline 1. & $\begin{array}{l}\text { Statement or description of the company's strategy and } \\
\text { objectives; may include strategies and common goals, } \\
\text { financial, marketing and social }\end{array}$ & & V & V \\
\hline 2. & $\begin{array}{l}\text { The description of the impact of the strategy on the results of } \\
\text { the present and the foreseeable future or }\end{array}$ & & $\mathrm{V}$ & \\
\hline 3. & $\begin{array}{l}\text { A description of the policies pursued by the company to } \\
\text { ensure management continuity }\end{array}$ & & & $\mathrm{V}$ \\
\hline B. & NON-FINANCIAL INFORMATION & & & \\
\hline 4. & $\begin{array}{l}\text { Chart or a description that explains the division of authority } \\
\text { and responsibility within the organization }\end{array}$ & $\mathrm{V}$ & $\mathrm{V}$ & $\mathrm{V}$ \\
\hline 5. & $\begin{array}{l}\text { Description of research and development programs; which } \\
\text { can include the location policy activity, number of } \\
\text { employees and the results achieved }\end{array}$ & & V & \\
\hline 6. & $\begin{array}{l}\text { Information on the main product or service that the company } \\
\text { provides }\end{array}$ & $\mathrm{V}$ & $\mathrm{V}$ & $\mathrm{V}$ \\
\hline 7. & $\begin{array}{l}\text { Information on orders from buyers who have not been met } \\
\text { and sales contracts will be realized in the future }\end{array}$ & & & \\
\hline 8. & $\begin{array}{l}\text { Information on market share analysis, can be qualitatively or } \\
\text { quantitatively }\end{array}$ & & V & \\
\hline 9. & $\begin{array}{l}\text { Information on competitor analysis, can be qualitatively or } \\
\text { quantitative }\end{array}$ & & $\mathrm{V}$ & $\mathrm{V}$ \\
\hline 10. & $\begin{array}{l}\text { Description of marketing network for goods and services the } \\
\text { company }\end{array}$ & & $\mathrm{V}$ & $\mathrm{V}$ \\
\hline 11. & $\begin{array}{l}\text { Statement or description of the company giving the same } \\
\text { opportunities, regardless of race religion and race }\end{array}$ & & & \\
\hline 12. & $\begin{array}{l}\text { Information on the number of employees working in the } \\
\text { company }\end{array}$ & & $\mathrm{V}$ & $\mathrm{V}$ \\
\hline 13. & $\begin{array}{l}\text { The descriptions of the conditions of health and safety in the } \\
\text { work environment }\end{array}$ & & & $\mathrm{V}$ \\
\hline 14. & $\begin{array}{l}\text { The description of the problems faced by the company in the } \\
\text { recruitment and employment policies adopted to address the } \\
\text { problem }\end{array}$ & & & \\
\hline \multirow[t]{2}{*}{15.} & Information on the physical level of output or use the & & $\mathrm{V}$ & \\
\hline & capacity achieved by the company in thexfutwdosrjournals.org & & & $3 \mid \mathrm{I}$ \\
\hline
\end{tabular}




\begin{tabular}{|c|c|c|c|c|}
\hline 16. & $\begin{array}{l}\text { The description of the impact of the company's operations on } \\
\text { the environment and the policies adopted to preserve the } \\
\text { environment }\end{array}$ & V & & $\mathrm{V}$ \\
\hline 17. & $\begin{array}{l}\text { Information on senior management, which may include your } \\
\text { name, experience and responsibilities.. }\end{array}$ & $\mathrm{V}$ & $\mathrm{V}$ & $\mathrm{V}$ \\
\hline 18. & $\begin{array}{l}\text { The description of the division of functional responsibilities } \\
\text { between the board of commissioners and directors }\end{array}$ & $\mathrm{V}$ & $\mathrm{V}$ & $\mathrm{V}$ \\
\hline 19. & $\begin{array}{l}\text { Information on value-added, can be qualitatively or } \\
\text { quantitatively }\end{array}$ & & & V \\
\hline 20. & $\begin{array}{l}\text { Information about the rate of return (return) is expected for a } \\
\text { project to be implemented by the company }\end{array}$ & & & $\mathrm{V}$ \\
\hline 21. & $\begin{array}{l}\text { Information about possible litiggasi by others against the } \\
\text { company in the future }\end{array}$ & & & \\
\hline 22. & $\begin{array}{l}\text { Information on those who try to obtain substantial ownership } \\
\text { of the shares of the company }\end{array}$ & & & $\mathrm{V}$ \\
\hline C. & FINANCIAL INFORMATION & & & \\
\hline 23. & $\begin{array}{l}\text { Information on the projected amount of sales next year, may } \\
\text { be qualitative or quantitative }\end{array}$ & & & \\
\hline 24. & $\begin{array}{l}\text { Information on projected sales profit next year, may be } \\
\text { qualitative or quantitative }\end{array}$ & & & \\
\hline 25. & $\begin{array}{l}\text { Information on the projected amount of cash flow next year, } \\
\text { may be qualitative or quantitative }\end{array}$ & & & \\
\hline 26. & $\begin{array}{l}\text { Description of investment or capital expenditures that have } \\
\text { been or will be implemented }\end{array}$ & & & $\mathrm{V}$ \\
\hline 27. & $\begin{array}{l}\text { Summary financial statistics including profitability ratios, } \\
\text { liquidity and solvency for } 6 \text { years or more }\end{array}$ & & & $\mathrm{V}$ \\
\hline 28. & $\begin{array}{l}\text { The report contains elements of income or loss, as compared } \\
\text { to three years or more }\end{array}$ & $\mathrm{V}$ & $\mathrm{V}$ & $\mathrm{V}$ \\
\hline 29. & $\begin{array}{l}\text { The report includes a balance sheet elements compared to } \\
\text { three years or more }\end{array}$ & $\mathrm{V}$ & $\mathrm{V}$ & $\mathrm{V}$ \\
\hline 30. & $\begin{array}{l}\text { Information detailing the amount spent on employees, which } \\
\text { may include salaries and wages, benefits and deductions }\end{array}$ & $\mathrm{V}$ & $\mathrm{V}$ & \\
\hline 31. & $\begin{array}{l}\text { Information on the number of annual compensation paid to } \\
\text { boards of commissioners and direction }\end{array}$ & $\mathrm{V}$ & & V \\
\hline 32. & $\begin{array}{l}\text { Information about the cost of being separated into fixed and } \\
\text { variable components }\end{array}$ & & & \\
\hline \multirow[t]{2}{*}{33.} & $\begin{array}{l}\text { The description of the impact of inflation on corporate assets } \\
\text { or the present and the foreseeable future }\end{array}$ & & & $\mathrm{V}$ \\
\hline & NUMBER & 9 item & 15 item & 20 item \\
\hline
\end{tabular}

\section{DISCUSSION}

Based on the table, it can be noted that, of the three companies researched about 33 items Voluntary Disclosure, showed that, PT. BAT Indonesia Tbk, is a relative lack of (adequate) Voluntary Disclosure submit as many 9 item $(27.27 \%$ ), followed by PT. Gudang Garam Tbk, providing adequate information as many as 15 items (45.45\%), and PT. HM. Sampoerna the most information (Full) by 20 items $(60.60 \%)$.

Further terms of the three types of information conveyed to the public, it can be seen as follows: 1. PT. BAT Indonesia Tbk,:

a. Strategic information, not inform..

b. Non-Financial Information, informing 5 items.

c. Financial information, inform the 4 items..

2. PT. Gudang Garam Tbk,

a. Strategic information, inform 2 items.

b. Non-Financial Information, informing 10 item..

c. Financial Information, Item 3 informs,.

3. PT. HM. Sampoerna Tbk,.

a. Strategic information, inform the second item,.

b. Non-Financial Information, informing 12 items,.

c. Financial Information, informing 6 items..

From the description above it can be seen that each company provide a description of the pressure and weight of different disclosure. For PT. BAT Indonesia Tbk, a financial disclosure information considered important to convey to the public, from the information strategy and non-financial information. This is because the company considers financial disclosure can provide important and relevant information to users of financial 
statements so as to help them both investors and shareholders, in making decisions in the best way. By providing information that is not too much inevitable presentation of information that is too detailed and too much, so instead complicate statement users to understand the information that is important, and difficult in interpretation financial statements. This would suit a variety of empirical research in companies going public in the United States (PT BAT Indonesia Tbk is also an American-based tobacco company) which states that: "Empirical studies and review of the literature provides evidence that firms in Americans reluctant to increase financial disclosure without pressure and coercion of the accounting profession and the government ". Even if "they realize that disclosure is vital for optimum decision-making by the investor and for the capital stable. Submission disclosure a slap in time, tends to prevent explosions changing news about the future of the company. Achieving timely disclosure also provides great confidence Overarching financial information ".

This is different from the two other companies, namely PT. Gudang Garam Tbk and PT. HM Sampoerna, the two companies company tend to provide more extensive information than the PT. BAT Indonesia. However, in PT. Gudang Garam Tbk., In terms of financial disclosure are the most minimal information to the public, of the 11 items of financial information PT. Gudang Garam Tbk, only give as much information as any 3 items, the profit and loss statement elements, elements of balance and information about shopping the company to employees. Minimal information about finances is not independent of the ownership structure of the PT. Gudang Garam Tbk, which is still dominated by the family. At PT. HM Sampoerna, compared with the two companies previously shown Voluntary Disclosure wider than the 33 elements studied about information provided to the public, as many as 20 items. Compared with two other companies as well as the number of items that the public informed on the many that is equal $60.60 \%$ of the total items examined. However, based on the theory of disclosure in financial reporting, the findings made by researchers can be categorized under fair disclosure, because "implied ethis goals to give equal treatment to all parties who are potential readers of the financial statements", which are presented to the public..

The implications are felt by PT. HM Sampoerna Tbk of informing the wider, as happened around the year 2000-2001 has been a significant influence on the demand for labor welfare. On the other hand with a broader expression, particularly in the item strategic and non-financial, have shown that the PT. HM Sampoerna can give an idea to the public as a company that has a good prospect and in good shape, especially in terms of the welfare of employees (human resources) were employed either of the expenditure, the age structure of the labor utilization, education, etc., as can be seen in Similarly, the data table when viewed from the financial information presented indicates that liquidity, Solvency and Profitability was showing an increasing trend from year to year..

The existence of non-financial information, well-informed strategic and non-financial information, by PT. Gudang Garam Tbk and PT. HM Sampoerna Tbk is important also informed the public, due to both nonfinancial elements, is considered to provide an argument as well as other information can be the basis of the financial statements that inform the public.

\section{Conclusions And Recommendations}

Based on the analysis of the 33 items of voluntary disclosure are examined in this study, it can be concluded as follows:.

1, the Voluntary Disclosure Decision-making in companies that have gone public have no uniform framework, of the three categories of information are researched, which include: (1). Strategic Information, (2). Non Financial Information and (3). Financial Information. These differences occur not independent, the management's view of these questions: (1). To whom should disclose information? (2) What is the purpose of such information? (3) How much information should disclose? consistent with the notion the management company. This is what distinguishes extensive voluntary disclosure between PT. BAT Indonesia Tbk, in contrast to PT. Gudang Garam Tbk, and PT. HM. Sampoerna Tbk.

2 , of the types of information disclosed to the public, showing that, not all companies that have gone public felt the need to express all types of information to the public. There are certain companies who view additional information (information of strategic and non-financial information), should not disclosed thorough public. However, financial information, even if minimal of the three companies studied, considered it necessary to be disclosed to the public in the annual report, as the liabilities of the company which has been going public. Thus, the view of the management, will determine the extent to which widespread voluntary disclosure was adjudged to information the public..

3, Disclosures topic of strategic information and non-financial information as additional information, is highly dependent on the views of the company on whether to give expression to the public. There is a tendency of the three companies studied, to only give expression to the public about financial information, only the financial information that has been going on in the company. The information that are projections or estimates will occur in accordance with the planning or target firms tend not informed the public, for example: Information on the projected amount of sales the following year, Information on projected sales profit next year, the projected 
amount of information regarding the cash flow next year, etc.. Because it is too risky if the company can not achieve the target as it has been informed to the public. Similarly, the information that is sensitive in the eyes of the public, the three companies researched choose not to provide information to the public, for example: corporate statement or description of giving equal opportunity, regardless of race, religion and race (Sara)..

4, of the three companies studied, showing that the information submitted through the Annual Report (Annual Financial Statements) in the capital market (Surabaya Stock Exchange) is associated with a radar analysis, suggests that given sufficient information for investors to know the development of the company. However, to give more insight on the medium and long term users of financial statements, with additional information such as: number of employees, number of direct labor, labor structure, salaries, data basis, the highest and lowest salaries, only PT. HM. Sampoerna can clearly give an idea about the direction and information to provide an overview of productivity and growth.

\section{Suggestion}

1 , the interest of the development of the company's management, as well as to comply with the provisions on transparency and information disclosure provisions of the financial statements, in order to not cause a misleading interpretation as well as to gain public confidence (Public Trust). To avoid these assumptions are not objective Voluntary Disclosure of users, should companies that have gone public to provide sufficient additional information. Whether it is including in the Strategic disclosure type of information, non-financial information and financial information it self.

2, the Financial Accounting Standards Board recommended that make rules and standard systematic though not to the things that are detailed in the company's financial reporting that has been going public. Financial reporting that existed at the third annual report of the companies researched, showing that there is no standard workflow on the content of the report. This ultimately makes the management in providing information to the public, relying on assumptions of their own to gain public confidence. In addition, the investor or prospective investor may create the perception is less precise, especially those who do not understand accounting in particular, so as not to hurt the feelings of the company in the future if they experience a loss.

3 , the existence of a fundamental investor (oriented to long-term investment decisions) require additional information particularly strategic and non-financial information, which involves information about human resources and all aspects related to the management, therefore, according to the writer's time is presented to the User Annual Report as an introduction that can provide direction and confidence to investors or potential investors, so the analysis of financial statements which disclose the company can be known about the state and prospects of development of the company's productivity and growth. So it can provide more confidence to investors or potential investors will have confidence in a company that is going public..

4, Today, as a result of the democratization of society, demands for transparency in a company that has gone public already can not be ignored anymore. However, of the three companies surveyed indicated that the issue of human resources, both concerning the equality of the right in the career, salary, incentive system seems still taboo to openly disclose to the public. Advice writer, deals with the issue, the company should have gone public have begun to open up to provide information to the public. Because it will be able to provide information to investors or prospective investors in the broader scale, to be able to analyze more about the system of human resource development in the company in a professional environment, so as to provide a more complete picture about the company's ability to maintain and obtaining a quality workforce. This is important because in the midst of an increasingly competitive competition, workforce development systems that promote professionalism, will greatly affect the performance of the company.

\section{References}

[1]. Meek, Gary K. Clare b, Robert and Sidney J Gray. 1995. “ Factor Influencing Voluntary Annual Report Disclosure by U.S. U.K. and Contenental European Multinational Corporation “. Journal of Inernational Business Studies 26 (third Quarter) $555-575$.

[2]. Hendriksen dan Breda, 1992, accounting theory, http://www.getbookee.org/hendriksen-van-breda-accounting-theory

[3]. (Jensen dan Meckling 1976. Theory of the firm: http://www.sciencedirect.com/science/article/pii/0304405X7690026X

[4]. Moleong, 2000. “Metode Penelitian Kualitatif”. PT Remaja Rosdakarya, Bandung.

[5]. Nasution, 1996. “ Metode Penelitian Naturalistik Kualitatif”. Tarsito, Bandung.

[6]. Strauss dan Corbin, 1990, Basics of Qualitative Research: Techniques and Procedures for.

[7]. Developing Grounded Theory, on Amazon.com

[8]. Suripto, 1998, Kesalahan dalam Soal Mengelola Buku Jurnal; Tugas Riset Akuntansi; Tugas Riset Akuntansi; Tugas riset akuntansi;

[9]. Theodorus M. Tuananakotta , 2000,, Sumbangan akuntan dalam pemulihan sektor keuangan, http://www.amazon.com/Theodorus-MTuanakotta/e/B001JOATCK

[10]. Hendriksen, 1990,, http://www.food.dtu.dk/English/Publications/Search_publications.aspx 